\title{
Purification and some serological relationships of tomato spotted wilt virus isolates occurring on peanut (Arachis hypogaea) in the USA
}

\author{
P. SREENIVASULU*, J. W. DEMSKI, \\ Department of Plant Pathology. University' of Georgia, Georgia Experiment Station, Griffin. G.A \\ 30223. USA
}

D. V. R. REDDY, R. A. NAIDUt and A. S. RATNA

Legumes Program. International Crops Research Institute for the Semi-Arid Tropics (ICRIS.AT). Patancheru PO, Andhra Pradesh 502324. India

A procedure for the purification of TSWV-Tx, a tomato spotted wilt virus isolate infecting peanuts in Texas, is described. A rabbit antiserum was produced. Several TSWV isolates occurring on peanut in the USA reacted to varying extents in ELISA with antisera to TSWV-Tx and to Greek TSWV isolates, but failed to react with antiserum to an isolate of TSWV from India. In reciprocal tests, antigens of the Indian TSWV failed to react with antisera to $T x$ and to the Greek isolates. Purified TSWV-Tx contained four polypeptide species of $78000,58000,54000$ and $27000 \mathrm{Da}$. In electro-blot immunoassays, all four polypeptides reacted with the homologous antiserum, and with antisera prepared against a Greek, a Dutch and an Australian isolate. None of the polypeptides reacted with the antiserum to the Indian isolate.

\section{INTRODUCTION}

Halliwell \& Philley (1974) first reported tomato spotted wilt virus (TSWV) on peanut (Arachis hypogaea) in Texas. In the early 1980s, the disease became a major constraint to peanut production in southern Texas, and it is currently considered to be one of the major peanut diseases on a global scale (Reddy et al., 1983; 1991). Besides peanut, TSWV infects many vegetables and ornamentals (Reddy \& Wightman, 1988; Cho et al., 1989). In

- Present address: Depariment of Virology. S.V. University, Tirupathi, Andhra Pradesh 517502, India.

+Present address: Department of Plant Pathology, Universily of Kentucky, Lexington, Kentucky, USA. serological tests, a TSWV isolate from southern Texas (TSWV-Tx) failed to cross-react with an isolate from India (TSWV-Ind), which also came from peanut (D. V. R. Reddy. A. S. Ratna. M. R Sudarshana and I. Kiran Kumar, unpublished data). We report here the puritication and polypeptide composition of TSWV-Tx, and the results of comparing host range and serological relationships with several other TSWV isolates from peanut in the USA.

\section{MATERIALS AND METHODS}

\section{Virus isolates, test plants and sap transmission}

Extracts from TSWV-infected peanut samples (obtained from Dr D. H. Smith, Texas A \& $M$ University), prepared in $005 \mathrm{a}$ potassium phosphate buffer, $\mathrm{pH}$ 7.0. containing $0.01 \mathrm{M}$ sodium sulphite, were inoculated to tigna unguic ularact. Early Ramshorn. The isolate TSW '-T,. obtained after five successive transfers of single lesions on cowpea, wats maintained in Nicotiana tabacum cv. Burley-21 or Datura vtram!mium!. For local lesion assay. Chenopodium amaranticolor and Petunia hybrida (le. 1970; Boswell \& Gibbs. 1983; Reddy et al., 1983) were used.

TSWV isolates trom Florida (TSWY-FI) and Georgia (TSWV-(ia) were collected irom peanut in 1987 (Sreenivasulu e't al., 1988). Each isolalte. following tive successive sungle-lesion tramefers from cowpeal. Was propagated in 1 rubacrum cv. Burley-21. 


\section{Heterologous antisera}

An antiserum to TSWV-Ind was obtained from the ICRISAT collection. Antisera to an Australian (TSWV-Aus), a Greek (TSWV-Grk) and a Dutch (TSWV-NI) isolate were generous gifts from Drs D. Mossop, G. V. Gooding Jr and D. Peters, respectively.

\section{Virus purification}

All purification steps were followed in a cold room at c. 4 C. Systemically infected $N$. tabacum cv. Burley-21 or A. hypogaea leaves were homogenized in a Waring blender in $0.1 \mathrm{M}$ potassium phosphate buffer, $\mathrm{pH}$ 7-0, containing $0.01 \mathrm{M}$ sodium sulphite (PPBS) $(3 \mathrm{ml} / \mathrm{g}$ tissue). The homogenate was squeezed through four folds of cheesecloth, and centrifuged at $5000 \mathrm{~g}$ for $15 \mathrm{~min}$. Polyethylene glycol (MW 8000, Fisher Scientific Co.) and $\mathrm{NaCl}$ were added at $4^{\prime \prime}$ " and $0.2 \mathrm{M}$, respectively, and after $1.5 \mathrm{~h}$ the precipitate was collected by centrifugation at $12000 \mathrm{~g}$ for $20 \mathrm{~min}$. The pellets were suspended in PPBS $(0.3 \mathrm{ml} / \mathrm{g}$ initial tissue) and clarified at $8000 \mathrm{~g}$ for $15 \mathrm{~min}$. The supernatant was layered onto a 10.40$)^{\prime \prime}$ linear sucrose gradient in PPBS (prepared by adding $8.0 \mathrm{ml}$ each of $10,20,30$ and $40 " \% \mathrm{w} v$ sucrose and leaving overnight at $4 C$ ) and centrifuged at 25000 r.p.m. for $\mathrm{l}$ h in a Beckman SW28 rotor. A light-scattering zone $(4+5 \mathrm{~cm}$ from the bottom) was withdrawn, diluted in PPBS, and layered onto $25-50 \%$ linear sucruse gradients prepared as before. The tubes were centrifuged for $4 \mathrm{~h}$ at 25000 r.p.m. as above. A lightscattering zone $(3.8-4.5 \mathrm{~cm}$ from the bottom) was collected and diluted in PPBS. The virus was pelleted at 35000 r.p.m. for $1.5 \mathrm{~h}$ in a Beckman R40 rotor

\section{Antiserum production}

Purified virus (from $100, \boldsymbol{g} N$. tahacum tissue, suspended in $0.05 \mathrm{M}$ potassium phosphate buffer. pH 7.0, containing $0.87 \%, \mathrm{NaCl})$ was emulsified with an equal volume of Freund's incomplete adjuvant and injected intramuscularly into two New Zealand White inbred rabbits. Five injections were given at weckly intervals. The rabbits were bled at weekly intervals after the last injection

\section{Enzlme-linked immumosorhe'nt assay' (ELISSI)}

The method used wals similar to the direct antigen-coating procedure of Hobbs at al. (1987).
The TSWV isolates used were those maintained in N. tabacum cv. Burley-21. Crude extracts of healthy plants were prepared in $0.05 \mathrm{M}$ sodium carbonate buffer, $\mathrm{pH} 9 \cdot 6$. The antisera were crossadsorbed with such extracts for $45 \mathrm{~min}$ at $37^{\circ} \mathrm{C}$ (Hobbs et al., 1987). Protein A-alkaline phosphatase conjugate (Sigma Chemical Co., P-9650) at $0 \cdot 1 \mathrm{unit} / \mathrm{ml}$ and $p$-nitrophenylphosphate (Sigma) at $1 \mathrm{mg} / \mathrm{ml}$ were used. Plates were incubated in the dark either at room temperature $(22-25 \mathrm{C})$ for $3 \mathrm{~h}$, or overnight at $4 \mathrm{C}$. Results were recorded at 405 nm using a Dynatek ELISA reader

\section{Electrophoresis of cirus proteins}

The polypeptides from virus preparations purified from A. hypogaea were analysed by polyacrylamide gel electrophoresis (PAGE) in slab gels, essentially as described by Laemmli (1970). Proteins from healthy $A$. hypogaea leaves, obtained by a purification procedure similar to that used for the virus. served as controls. The concentrations of the resolving and stacking gels were 10 and $4 \%$, respectively. Purified virus samples and marker proteins were electrophoresed at $25 \mathrm{~V}$ for $16 \mathrm{~h}$. Phosphorylase B $(97400)$, bovine serum albumin $(66200)$, ovalbumin $142700)$. carbonic anhydrase $(31000)$ and soybean trypsin inhibitor (21000)(Biorad) were used as molecular weight markers.

\section{Electro-blot immunoassay}

After PAGE. polypeptides from purified virus preparations and from healthy plants were electro-blotted to nitrocellulose paper (Schleicher and Schull BA 85, $0 \cdot 45 \mu \mathrm{m}$ pore size) and probed with different antisera as described by Naidu et al. (1989). Various TSWV antisera were used at 1:500 dilution, and 1-naphthyl phosphate was used as substrate. Colour development was initiated by the addition of $25 \mathrm{mg}$ Fast Blue RR salt (Sigma) in $5 \mathrm{ml}$ water. Results were assessed visually

\section{RESULTS AND DISCUSSION}

Chlorotic spots and concentric rings appeared on peanut leaflets inoculated with TSWV-Tx 2 weeks after inoculation. Fully expanded leaflets below the terminal bud later became flaccid, with necrosis of the petiole and terminal bud. This led tocessation of apical grow th. and proliferation of axillary shoots tearing motlled and distorted leuflets. S! mptoms on selected hosts are given in Table 1 
Table 1. Symptoms induced by a tomato spotted wilt virus isolate from south Texas on various host plants

\begin{tabular}{lll}
\hline & & \multicolumn{2}{c}{ Symptoms } \\
\cline { 2 - 3 } Host plant & Local & \multicolumn{1}{c}{ Systemic } \\
\hline Capsicum annuum & CRS & CRS, M, LD \\
Chenopodium amaranticolor & CS or NS & - b \\
Datura stramonium & CRS & CS, M \\
Gomphrena globosa & CS & M \\
Lycopersicon esculentum & CS & M, N, B \\
Nicotiana tabacum cv. Burley-21 & CS or NS & CS or NS, NV. M, LD \\
N. glutinosa & CS or NS & N (rare) \\
Petunia hybrida & CS & - \\
Phaseolus vulgaris cv. Topcrop & CS & - \\
Vigna unguiculata cv. Early Ramshorn & CRS & CS (sometimes) \\
Vigna unguiculata cv. Clay & CRS & CS (sometimes) \\
Vinca rosea & BNS & M. LD \\
& & \\
\hline
\end{tabular}

a, bronzing; BNS, black necrotic spots: CRS, chlorotic ring spots: CS. chlorotic spots; $L D$, leaf distortion; $M$, mosaic: $N$, necrosis; $N S$, necrotic spots: NV, necrosis along lateral veins. Results were confirmed by assays on $r$. unguiculata.

${ }^{b}$ No symptoms observed; no infective virus recovered.

Table 2. Detection of tomato spotted wilt virus by ELISA using unadsorbed and crossadsorbed homologous antiserum

\begin{tabular}{|c|c|c|c|c|c|c|c|}
\hline \multirow{3}{*}{$\begin{array}{l}\text { Antigen } \\
\text { ( } N . \text { tabacum- } \\
\text { cv. Burley-21 } \\
\text { leaf extracts) }\end{array}$} & \multirow{3}{*}{$\begin{array}{l}\text { Dilutions } \\
\text { of antigen }\end{array}$} & \multicolumn{6}{|c|}{ Dilutions of antiserum } \\
\hline & & \multicolumn{3}{|c|}{ Unadsorbed } & \multicolumn{3}{|c|}{ Cross-adsorbed $^{b}$} \\
\hline & & $1: 200$ & $1: 1000$ & $1: 5000$ & $1: 200$ & $1: 1000$ & 1: 5000 \\
\hline Infected & $\begin{array}{l}10^{-2} \\
10^{-3}\end{array}$ & $\begin{array}{l}1.77^{c} \\
1.57\end{array}$ & $\begin{array}{l}1.55 \\
1.23\end{array}$ & $\begin{array}{l}0.67 \\
0.23\end{array}$ & $\begin{array}{l}1.84 \\
0.97\end{array}$ & $\begin{array}{l}0.69 \\
0.32\end{array}$ & $\begin{array}{l}0.33 \\
0.14\end{array}$ \\
\hline Healthy & $\begin{array}{l}10^{-2} \\
10^{-3}\end{array}$ & $\begin{array}{l}1.30 \\
1.01\end{array}$ & $\begin{array}{l}0.90 \\
0.88\end{array}$ & $\begin{array}{l}0.28 \\
0.26\end{array}$ & $\begin{array}{l}0.09 \\
0.07\end{array}$ & $\begin{array}{l}0.02 \\
0.00\end{array}$ & $\begin{array}{l}0.03 \\
0.02\end{array}$ \\
\hline
\end{tabular}

- Dilutions based on original weight of leaf tissue.

${ }^{b}$ Cross-adsorbed with healthy $N$. tabacum cv. Burley-2l leaf extracts as described by Hobbs $e t$ al. (1987).

cMean A $405 \mathrm{~nm}$ value for three replicates.

Initially, many methods were tried for the purification of TSWV-Tx (Black ef al., 1963; Mohamed et al., 1973; Tas et al., 1977; Francki \& Hatta, 1981). Preparations obtained by each procedure were analysed by SDS-PAGE. They contained several polypeptides, some of host origin. The method adopted is a modification of that reported for a TSWV-Ind isolate (ICRISAT. 1988). Purified virus retained approximately $5 \%$ of the infectivity present in crude plant extracts.
An antiserum produced against TSWV-Tx contained antibodies to healthy leaf extracts. However, after cross-adsorption with such extracts it could be used to detect virus in infected leaf extracts (Table 2). Weak reactions with healthy tobacco leaf extracts, observed for several TSWV antisera, could be minimized by cross adsorption with such extracts.

TSWV-Tx preparations gave high ELISA values with homologous. TSW' $\mathrm{V}-\mathrm{NI}$ and TSW $\mathrm{V}$. 
Table 3. Reactions of four tomato spotted wilt virus (TSWV) isolates in ELISA

\begin{tabular}{lccccc}
\hline & \multicolumn{5}{c}{ Antisera $^{b}$} \\
\cline { 2 - 6 } Isolates & TSWV-Tx & TSWV-Aus & TSWV-Grk & TSWV-NI & TSWV-Ind \\
\hline Texas & $1.80^{\circ}$ & 1.66 & 0.39 & 1.44 & 0.03 \\
Georgia & 1.67 & 1.21 & 1.28 & 1.08 & 0.07 \\
Florida & 0.04 & 0.09 & 0.09 & 0.06 & 0.03 \\
India & 0.02 & 0.08 & 0.06 & 0.09 & 1.24 \\
\hline
\end{tabular}

${ }^{\triangleleft}$ Viruses maintained in $N$. tabacum $\mathrm{cv}$. Burley-2l, used at $1: 100$ dilution.

${ }^{h} C$ ross-adsorbed with healthy $N$. tabacum cv. Burley-21 leaf extracts.

'Mean A $405 \mathrm{~nm}$ value for three replicates.

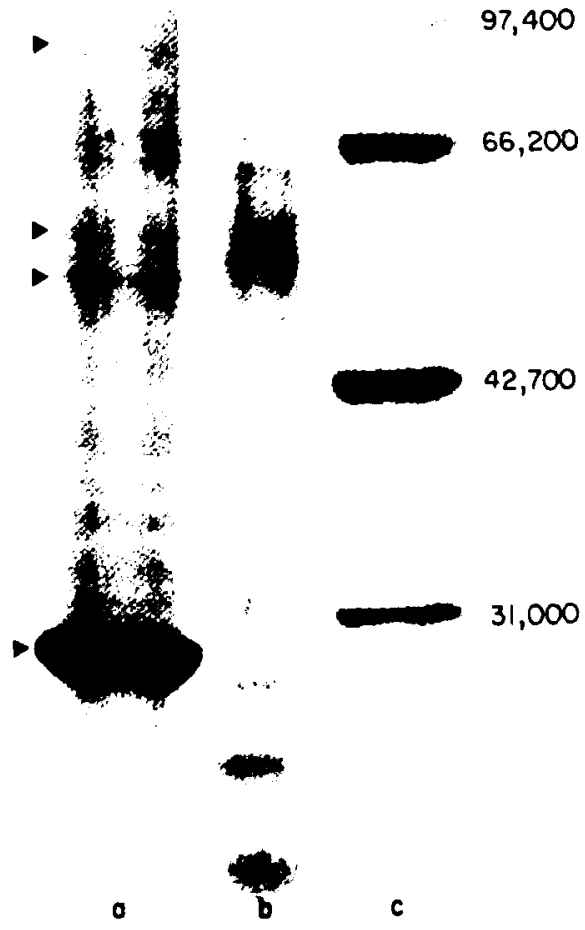

Fig. I. SLS polyatrylanode slab gel showing polypeplades larrous) af a lomalo spotled nilt virus (TSWS. Tx) solate (lane a), polypeptades from comparable hat healthy peanul leaves (hane h). and molecular weggh markers (lanec)

Aus antiscrat, hut reacled weakly with anliserum (1) TSWV-cirk. The TSWV-(jal isolalle reacled srongly with TSWV-Tx. TSWV-cirk. TSWV.

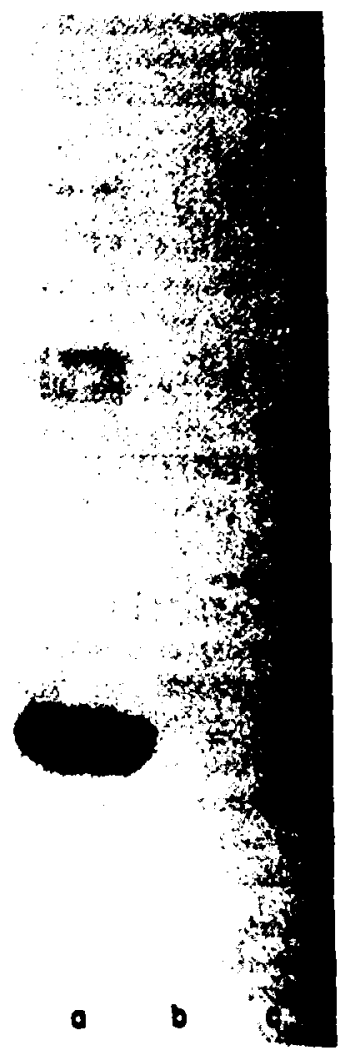

Fig. 2. Immuno-blots of polypeptides of a tomato spotted wilt virus (TSWV-T $x$ ) isolate after probing with TSWV-Tx antiserum (lane a), and with antiserum for an Indian isolate (lane b). Polypeptides from comparable hut healthy peanut leaf extract were probed with TSWV-Tr antiserum (lane $c$ ).

Aus and TSWV-NI antisera. TSWV-TX and TSWV-Ga did not react with the antiserum to TSWV-Ind. TSWV-FI did not react with any of the antisera tested (Table 3). It thus appears that 
TSWV-FI and TSWV-Ind are the only isolates not reacting with TSWV-TX antiserum, indicating that they are serologically distinct.

Four virus-associated proteins of estimated molecular weight $78000,58000,54000$ and $27000 \mathrm{Da}$ were consistently detected by PAGE in infected but not healthy extracts (Fig. 1). Several minor virus-associated polypeptides were also observed, whose presence and concentration varied from sample to sample.

In electro-blot immunoassay, all the major proteins of TSWV-Tx could be detected with the homologous antiserum (Fig. 2) and antisera to the isolates Grk, Aus and Nl. TSWV-Ind antiserum did not react with any of the TSWV-Tx proteins, in agreement with the ELISA results. It is interesting that none of the polypeptides of TSWV-Tx reacted with TSWV-Ind antiserum. We presume that TSWV-Tx is similar to the TSWV strain isolated from lettuce (Cho et al., 1989). Whether the TSWV-Fl isolate is related to the TSWV isolate from Impatiens (Moyer et al., 1991), which is serologically distinct from the lettuce strain, is yet to be determined.

It is apparent from this study that several antisera should be used to determine serological relationships of TSWV isolates occurring in various peanut-growing regions of the world. In conducting surveys for TSWV, it would be useful to have a monoclonal antibody reacting with all virus isolates. Additionally, it is now essential to determine the host ranges of various TSWV isolates under similar conditions, so that such data can be used for diagnostic purposes.

\section{ACKNOWLEDGEMENT}

Submitted as ICRISAT Journal article No. 1064. We wish to thank Dr D. McDonald for his valuable comment and Drs G. V. Gooding Jr, D. Mossop and D. Peters for supplying antisera.

\section{REFERENCES}

Black L.M., Brakke M.K. \& Vatter A.E. (1963) Purification and electronmicroscopy of tomato spotted wilt virus. Virology 20, 120-130.

Boswell K.F. \& Gibbs A.J. (1983) V'irus Identitication Data Exchange: V'iruses of Legumes. $139 \mathrm{pp}$. Australian National University, Canberra.

Cho J.J., Mau R.F.L., German T.L., Hartman R.W.. Yudin L.S., Gonsalves D. \& Provvidenti R. (1989) A multidisciplinary approach to management of tomato spotted wilt virus in Hawaii. Plant Diseass 73. $375 \cdot 383$.

Francki R.I.B. \& Hatta T. (1981) Tomato spolted wilt virus. In: Handbook of Plani Virus Infertions and
Comparatice Diagnosis (Ed. by E. Kurstak), pp. 491512. Elsevier. Amsterdam.

Halliwell R.S. \& Philley G. (1974) Spotted wilt of peanut in Texas. Plant Diseasc Reporter 58, 23-25.

Hobbs H.A., Reddy D.V.R., Rajeshwari R. \& Reddy A.S. (1987) Use of direct antigen coating and protein A coating ELISA procedures for detection of three peanut viruses. Plant Discase 71, 747749.

le T.S. (1970) Tomato spotted wilt virus. C.MI A.AB Descriptions of Plant Viruses no. 39.

ICRISAT (1988) ICRISAT Annual Report 1987. International Crops Research Institutc for the Semi Arid Tropics. Patancheru. Andhra Pradesh 502 324. India. p. 324

Latemmli U.K. (1970) Cleavage of structural proteins during the assembly of the head of bacteriophage $T$ t. Nature 227, 680-685.

Mohamed N.A., Randles J.W. \& Francki R.I.B. (1973) Protein composition of tomato spotted wilt virus. lirology 56, 1221

Moyer J.W., Law M.D. \& Urban L.A. (1991). Characterization of a serologically distinct TSWV-like virus from Impatiens. In: Virus-Thrips - Plant Interaction of Tomato Spotted Wilt l'irus. USDA. Beltsville, Maryland. 53-59.

Naidu R.A., Harikrishnan R., Manohar S.K., Reddy D.V.R. Ratna A.S., King S. B. \& Bandyopadhyay R. (1989) The occurrence of maize mosaic virus on sorghum in India. Annals of Applied Biology 114, 301-310.

Reddy D.V.R., Amin P.W., McDonald D. \& Ghanekar A.M. (1983) Epidemiology and control of groundnut bud necrosis and other diseases of legume crops in India caused by tomato spotted wilt virus. In: Plant L'irus Disease Epidemiology (Ed. by R. T. Plumb \& J. M. Thresh), pp. 98-102. Blackwell Scientific Publications, Oxford.

Reddy D.V.R. \& Wightman, J.A. (1988) Tomato spotted wilt virus: thrips transmission and control. In: Aulunces in Disease bitor Research (Ed by K. F Harris), Vol. 8 pp. 203-220. Springer-Verlag. New York.

Reddy D.V.R., Wightman J.A., Beshear R. J. . Highland B.. Black M. Sreenivasulu P. Dwivedi S.L., Demski J.W., McDonald D., Smith J.W. \& Smith D.H. (1991) Bud necrosis - a disease of groundnut caused by tomato spotted wilt virus. ICRIS.AT Informarion Bulletin. International Crops Research Institute for the Semi Arid Tropics, ICRISAT. Patancheru PO. Andhra Pradesh 502 324. India. no. 31. $20 \mathrm{pp}$

Sreenivasulu P.. Demskı J W . Reddy D V.R.. Mısarı S.M., Olorunju PE \& Kuhn C.W (1988) Tomato spotted wilt virus and strans of peanut mottle virus that mimic TSW V symptoms in peanut in Georglit Plant Discase 72, s4n

Tas P.W.L., Buerjan J.L. \& Paters D (1977) Purificiation and sirotogucal analysis of tomato spotted will virus. Netherhands Journal of Plam Parholog! 83, ol 72. 
This document is a scanned copy of a printed document. No warranty is given about the accuracy of the copy. Users should refer to the original published version of the material. 